\title{
Habitat proximity exerts opposing effects on key ecological functions
}

Tyson S.H. Martin ${ }^{1 *}$, Andrew D. Olds ${ }^{2}$, Asier B.H. Olalde ${ }^{3}$, Charlotte Berkström³ , Ben L.

Gilby $^{2}$, Thomas A. Schlacher ${ }^{2}$, Ian R. Butler ${ }^{4,5}$, Nicholas A. Yabsley², Maria Zann ${ }^{6}$, Rod M. Connolly ${ }^{1}$

1. Australian Rivers Institute - Coast and Estuaries, and School of Environment, Griffith University, Gold Coast, QLD, 4222, Australia.

2. School of Science and Engineering, University of the Sunshine Coast, Maroochydore, QLD, 4558, Australia.

3. Department of Ecology, Environment \& Plant Sciences, Stockholm University, 10691 Stockholm, Sweden.

4. Research School of Biology, The Australian National University, Canberra, ACT, 0200, Australia.

5. CoraLogic Environmental Consulting, Cook, ACT, 2614, Australia.

6. Remote Sensing Research Centre, School Earth and Environmental Sciences, The University of Queensland, Brisbane, QLD, 4072, Australia.

${ }^{*}$ Corresponding author: Tyson Martin; Email: tyson.martin@griffithuni.edu.au

Phone: +6175552 8064; Fax: +6175552 7785

Running title: Habitat proximity exerts opposing effects on ecological functions

Keywords: seascape, landscape, ecology, predation, herbivory, piscivory, browsing, fish, heterogeneity, coral reefs, asymmetry, connectivity 


\begin{abstract}
Context Connectivity is an important property of landscapes that shapes populations and ecosystem functioning. We do not know, however, whether and how different types of spatial linkages combine to influence ecological functions, and this hampers their integration into conservation planning.
\end{abstract}

Objectives We used coral reef seascapes in eastern Australia as a model system to test whether the proximity of other reefs (habitat proximity) or the proximity of other habitats (seascape proximity) exert stronger effects on two key ecological functions (herbivory and piscivory).

Methods We measured rates of herbivory (on fleshy macroalgae) and piscivory (on prey fish) on reefs that differed in their proximity to both other reefs and nearby mangroves and seagrass.

Results The extent of habitat proximity between reefs significantly influenced both ecological functions, but in different ways: isolated reefs supported high herbivory but low piscivory, whilst, conversely, reefs that were closer to other reefs supported high piscivory but low herbivory. This was not caused by herbivores avoiding their predators, as the dominant piscivores (small predatory snappers) were too small to consume the dominant herbivores (large rabbitfishes). Seascape proximity (e.g. distance to mangroves or seagrass) was less important in shaping ecological functions on reefs in this system.

Conclusions We suggest that the effects of seascape configuration on ecological functions depends on the type of spatial linkage, and the ecological functions in question. To better integrate connectivity into conservation, we must develop a deeper understanding of how different spatial linkages combine to shape ecosystem functioning across landscapes. 


\section{Introduction}

When animals move among habitats they link populations, food webs and ecological functions across landscapes (Lundberg et al. 2008; Massol et al. 2011). The significance of these spatial linkages is widely appreciated because many animals rely on multiple habitats throughout their lives (Kool et al. 2013; Nagelkerken et al. 2015). Consequently, connectivity has become an increasingly important consideration in spatial conservation planning (Tscharntke et al. 2012; Magris et al. 2016). High connectivity can improve conservation outcomes by: increasing the abundance and diversity of species inside reserves (Bennett 1999; Olds et al. 2012a); promoting the export of harvested species from reserves (i.e. spillover) to areas where they can be captured (Brudvig et al. 2009; Harrison et al. 2012); and linking populations among different reserves in conservation networks (Tewksbury et al. 2002; Beger et al. 2010). The effects of connectivity can also modify the spatial distribution of ecological functions (e.g. propagule dispersal, pollination, herbivory, predation, carbon processing) across terrestrial, freshwater and marine landscapes (e.g. Nystrom and Folke 2001; Bernhardt and Leslie 2013; Bregman et al. 2016). Understanding how connectivity shapes ecosystem functioning and ecological resilience is a central goal of landscape ecology (Lundberg and Moberg 2003; Cumming 2011), but the functional effects of connectivity are rarely tested with empirical data, and most studies use patterns in species richness and abundance as surrogates for ecological functions (e.g. Staddon et al. 2010; Pagès et al. 2014; Yabsley et al. 2016).

Animals that move among ecosystems usually link multiple ecological functions across landscapes (Crooks and Sanjayan 2006; Cumming 2011; Olds et al. 2016). For example, birds move between nesting sites and feeding areas, modifying pollination rates, seed dispersal and predation across terrestrial landscapes (Mueller et al. 2014; Pérez-Hernández et al. 2015; Kleyheeg et al. 2017). The migration of fish between marine and freshwater systems, and among tropical marine habitats, also alters herbivory, predation, carbon processing and primary production in coastal seascapes (Bostrom et al. 2011; Nagelkerken 
et al. 2015; Olds et al. 2017). These effects of connectivity on ecological functions are shaped by the dispersal capability of organisms, the spatial patterning of habitats in landscapes, and by biological interactions between species (e.g. predators, prey, competitors) (Lundberg and Moberg 2003; Sheaves 2009; Cumming 2011). However, because the functional effects of connectivity are rarely tested with empirical data, we do not know to what degree, and how consistently, ecological functions are affected by connectivity (Pagès et al. 2014; Olds et al. 2016). The effects of connectivity on ecosystem functions might differ between the type and spatial scale of the connectivity, and additionally, landscape features that benefit one ecological function might adversely affect others (Beger et al. 2010; Yabsley et al. 2016). Connectivity is also notoriously difficult to quantify, as it depends on not only the spatial configuration of habitats, but also the strength of vectors that move between them such as tides, wind and ocean currents, and the biological movements of the animals themselves (Bélisle 2005). Data on the strength of these vectors and the movement patterns of its inhabitants is unavailable for many areas, hampering the uptake of connectivity into conservation planning. To better integrate spatial linkages into conservation planning, we therefore require empirical data on how simple, easily measured aspects of connectivity such as spatial proximity affect ecosystem functioning across landscapes (Olds et al. 2016).

In coastal seascapes, fish move among habitats to feed and reproduce (Nagelkerken 2009; Sheaves 2009; Pittman and Olds 2015). Spatial linkages among habitat patches of the same type (i.e. habitat proximity), and between different habitats (i.e. seascape proximity), structure the abundance, diversity and composition of fish assemblages in seagrass meadows, mangrove forests, and on coral reefs (reviewed by Bostrom et al. 2011; Berkstrom et al. 2012; Igulu et al. 2014; Nagelkerken et al. 2015). Proximity can also modify the distribution of key ecological functions performed by fishes, with higher rates of both herbivory and predation often reported from seagrass, mangroves and reefs that are closer together (i.e. within $1 \mathrm{~km}$ of each other) (Valentine et al. 2008; Hammerschlag et al. 2010; 
Olds et al. 2012c; Downie et al. 2013; Peterson et al. 2013). It is not clear, however, whether the effects of proximity on herbivory and predation occur over different scales, or how they are affected by the type of spatial linkage. For example, is the proximity of other reefs, or the proximity of different types of habitats such as mangroves and seagrass more important for ecosystem function?

We used inshore coral reef seascapes in Hervey Bay, eastern Australia, as a model system to examine how proximity shapes multiple ecosystem functions across landscapes, and test whether patterns in these ecosystem functions align with the distribution of the fish that provide them. In Hervey Bay, fish can migrate tidally between coral reefs, mangroves and seagrass meadows (Zann 2012), and the spatial configuration of these habitats affects the diversity and abundance of both herbivorous and predatory fishes (Martin et al. 2015). Here we test whether, and how, habitat and seascape proximity combine to shape two key ecological functions on coral reefs: herbivory (consumption of fleshy macroalgae) and piscivory (predation on live fish). 


\section{Methods}

\section{Study seascape}

To measure the effects of habitat and seascape proximity on fish assemblages and ecological functions, we performed underwater visual censuses (UVC) and deployed fleshy macroalgae (herbivory) and live fish (piscivory) assays on ten coral reefs in Hervey Bay, eastern Australia (Fig. 1). Hervey Bay is a subtropical embayment that supports inshore coral reefs, mangroves and seagrass beds (Zann 2012; Martin et al. 2015), making it an ideal seascape to test for effects of habitat and seascape proximity on ecological functions. Reef sites were separated by a minimum of $1 \mathrm{~km}$ and each was surrounded by seascapes of varying configuration. Sites spanned a gradient from low to high levels of seascape and habitat proximity. For example, some sites only contained focal reef (i.e. the reef the site was located on), whereas others were nearby to mangroves forests, seagrass beds, and other reefs (Fig. 1). In addition, although the overall mapping scale can make it difficult to see fine detail, we point out that in the western bay, sites varied according to the size of the focal reef, as well as the area, and distance to other reef and mangrove habitats (Fig. 1). To summarise, the seascape configuration surrounding each site is very different, minimising the risk of spatial autocorrelation.

\section{Calculating proximity metrics and reef characteristics}

We calculated habitat and seascape proximity metrics, quantified within-reef characteristics and measured the distance from each reef to anthropogenic influences using existing benthic habitat maps, ArcGIS and Google Earth Pro (sources: Queensland Department of Science; Information Technology and Innovation; Campbell and McKenzie 2004; Martin et al. 2015; Zann et al. 2017). As seascape studies need to be scaled to the species and ecological functions of interest (Grober-Dunsmore et al. 2009), we adopted a multi-scale approach, capturing habitat-use patterns of species that respond to seascape structure at differing scales (Pittman and Brown 2011; Olds et al. 2012b; Berkstrom et al. 2013). Habitat 
and seascape proximity were quantified at each site by calculating: (1) the proximity of nearby reefs (habitat proximity) (Engelhard et al. 2017); (2) the proximity of adjacent mangrove and seagrass habitats (seascape proximity) (Olds et al. 2012b); (3) the number of reef, seagrass or mangrove patches (habitat richness); (4) the diversity of habitats (habitat diversity); and (5) the area of focal reef habitat (the reef that the piscivory and browsing assays were located on) within 250, 500, 750 and 1000 m (radii) circular buffers centred on reef sites (Table 1). We used these buffer sizes because fish in the region have previously been shown to respond to seascape structure at distances of 500-1000 m (Martin et al. 2015). The use of Euclidean distance approaches (i.e. proximity) to provide a proxy for connectivity has previously been criticised for being overly simplistic (Moilanen and Nieminen 2002; Saura and Pascual-Hortal 2007), however its inherent simplicity gives it great appeal to conservation planning (Calabrese and Fagan 2004). Given that we lack quantitative information about vectors likely to impact connectivity between habitats in this area, such as the direction and speed of water movement, we therefore cannot speculate about the strength or direction of these connections. In these circumstances, we consider Euclidean straight-line distances (proximity) an effective estimate of connection strength (and one that has been used previously in similar situations e.g. Olds et al. 2012 a, b; Martin et al. 2015). To check that the effects of proximity were not modified by within-reef characteristics or anthropogenic impacts, for each site we also quantified the amount (\%) of hard substrate (coral and bedrock), live coral, and algal cover (within-reef characteristics) using benthic photo transects (Butler et al. 2013), and calculated distance to nearest no-take marine reserve and distance to nearest boat ramp (a proxy for anthropogenic influences such as fishing pressure (Stuart-Smith et al. 2008)) (Table 1). Values for each of these variables remained the same regardless of buffer size. No reef sites were located inside reserves.

\section{Herbivory experiments}


We quantified spatial variation in browsing herbivory by measuring the rate of consumption of brown algae (Sargassum flavicans), a genus widely used in browsing studies throughout the Indo-Pacific (e.g. Hoey and Bellwood 2010; Bennett and Bellwood 2011; Michael et al. 2013; Yabsley et al. 2016). Sargassum occurs seasonally in Hervey Bay and is consumed by most browsing herbivores in the region (Yabsley et al. 2016). We collected Sargassum from other nearby rocky areas because, at the time of the experiment, the cover of Sargassum was low across all reef sites. This consistently low cover of Sargassum on reef sites, was therefore unlikely to affect herbivory on deployed assays and fish that detected assays usually consumed all of the deployed algae (Table 2). Natural algal cover in the region was dominated by Lobophora variegata and Asparagopsis taxiformis, both of which are not preferred food for rabbitfish (Siganidae) (Paul et al. 1992; Pillans et al. 2004), which are the dominant herbivore in the region (Martin et al. 2015), usually observed feeding on filamentous turf algae. In summary, as there was no Sargassum in the area, and other common algae are preferred by rabbitfish, the cover of each is unlikely to have affected herbivory rates. Sargassum assays were deployed for $24 \mathrm{hrs}$, which was shown in a pilot study to result in a relatively even spread of assays that had either been consumed, or left untouched. We deployed 11 algal assays (ten experimental, one procedural control) composed of 2-3 Sargassum thalli, at each site, with algal weights recorded before and after deployment (e.g. Mantyka and Bellwood 2007; Yabsley et al. 2016). Deployments were 10$15 \mathrm{~g}$ in weight and 25-30 cm long. Minimum separation distance between assays was $6 \mathrm{~m}$ (visibility was $\leq 5 \mathrm{~m}$ ). One replicate per site served as a procedural control and was covered by a fish exclusion cage $(0.7 \times 0.7 \times 0.7 \mathrm{~m}, 10 \mathrm{~mm}$ monofilament mesh) to prevent herbivores from consuming the algae. Algal loss in procedural controls was minimal $(<1 \%)$. To identify browsing species that consumed Sargassum, we recorded three assays at each site for 4 hrs (using high-definition GoPro cameras).

\section{Piscivory experiments}


Experiments that tether live prey are commonly used to measure relative predation rates in aquatic ecosystems (e.g. Baker and Sheaves 2007; Dorenbosch et al. 2009; Hammerschlag et al. 2010; Bosiger and McCormick 2014; Dupuch et al. 2014; Pelicice et al. 2015). We conducted tethering experiments using common hardyheads (Atherinomorus vaigiensis; Atherinidae) as prey species. This species suited the study as it is abundant in all focal coastal habitats (reefs, seagrasses and mangroves), and is preyed upon by most mesopredators on the inshore coral reefs in this region (Olds et al. 2012a; Martin et al. 2015). Tethered hardyheads were deployed for $1 \mathrm{hr}$, which was shown in a pilot study to result in a relatively even spread of fish that had either been consumed, or left untouched. We deployed 25 prey fish at each site, with a minimum separation distance of $6 \mathrm{~m}$ (visibility $\leq 5 \mathrm{~m}$ ). Fish were tethered to coral by a thin monofilament fishing line (6 lb breaking strain, $50-80 \mathrm{~cm}$ long), which passed through the lower jaw and allowed fish to move as naturally as possible. Piscivory events were recorded when fish were absent from their tethers. At the end of the deployment, remaining fish were untied and released. To identify predator species that preyed on hardyheads, and confirm that uneaten fish remained attached to their tethers, we recorded ten fish deployments at each site for $1 \mathrm{hr}$ (using high-definition GoPro cameras). Video footage confirmed that no fish were able to break the tether and escape.

\section{Fish surveys}

We conducted five replicate underwater visual censuses (UVC) at each site to characterise fish communities (Olds et al. 2012a; Olds et al. 2013; Martin et al. 2015; Yabsley et al. 2016). Each replicate consisted of a $50 \times 4 \mathrm{~m}$ belt transect with at least $50 \mathrm{~m}$ between transects (Olds et al. 2012b). Despite the relatively poor visibility in the study region $(\leq 5 \mathrm{~m})$, these transects are an accurate method of counting fish as the observer can still clearly see $2 \mathrm{~m}$ either side of the transect (Olds et al. 2012a; Olds et al. 2013; Martin et al. 2015). Fish counts were performed at the same time of day as predation experiments, between 0900 and 1600 . The same diver carried out all surveys, within three hours of low tide, recording the abundance and total length of all fish greater than $5 \mathrm{~cm}$. We converted these data into 
biomass values using published length-weight relationships (Kulbicki et al. 2005). We classified fish as either browsing herbivores or piscivores (Table S4). UVC was performed at the completion of the piscivory and herbivory assays and all fieldwork was completed within a three week period (late March/early April, 2016) without breaks. Prior to the UVC surveys, the surveyor trained by estimating fish size on templates.

\section{Data Analysis}

The effects of habitat and seascape proximity on fish biomass, herbivory and piscivory were analysed using Boosted Regression Tree analysis (BRT) (Elith et al. 2008). BRTs combine the benefits of regression trees, models that relate dependent variables to predictors by iteratively partitioning the data into increasingly smaller groups, and boosting, a forward, stage-wise process that uses training data to compare residuals of simple models and combines these to improve model performance (Elith et al. 2008). BRTs can fit non-linear relationships, cope with collinearity among predictors and are ideal for situations where there are many predictor variables over multiple spatial scales (Olds et al. 2012b). They have been used successfully to assess the importance of seascape characteristics to fish (e.g. Pittman and Brown 2011; Olds et al. 2012b). BRT models were fitted using a Bernoulli distribution for presence/absence data, and a Poisson distribution for fish count data (Table 2). Predictor variables used in BRT models included habitat (i.e. reef proximity) and seascape proximity (i.e. proximity of reefs, mangroves and seagrass habitats; habitat richness and diversity) variables; and, area of focal reef habitat in 250, 500, 750 and $1000 \mathrm{~m}$ buffers (Table 1). BRT models also included within-reef characteristics and anthropogenic influences (Table 1). In BRTs, the learning rate controls the contribution of each tree to the model, while tree complexity determines the number of interactions that can be present in the model (Elith et al. 2008). We optimized model performance by comparing combinations of slow learning rates $(0.0001-0.001)$ and low tree complexities $(2-4)$ using the area under the receiver operating characteristic curve cross-validation (AUC CV) and total crossvalidation (Total CV) statistics (Pittman and Brown 2011). 
For each type of seascape scale variable (see Table 1), we performed individual BRTs to identify the scale at which proximity effects were most strongly correlated with fish biomass and ecological functions. The 'best' scale for each type of proximity was then included in a BRT, which tested for effects of proximity relative to variation in other seascape variables (see Table 1). Variables which showed an importance value of $>10 \%$ were then included in a final BRT, which tested the effects of proximity variables relative to variation in within-reef characteristics and anthropogenic influences. For example, coral reef proximity was most strongly correlated with herbivory at the $750 \mathrm{~m}$ scale; consequently, all subsequent analyses for herbivory used coral reef data at that scale. This process optimised selection of variables at scales relevant to the fish functional groups and ecological functions in question. It also allowed us to contrast the influence of proximity with possible confounding effects of variation in within-reef characteristics and anthropogenic variables in final BRT models. The fit of BRT models ranged from acceptable (AUC CV or Total CV >0.7), to outstanding $(>0.9)$ (Hosmer and Lemeshow 2000), suggesting that our final models were able to accurately interpret the effects of proximity, within-reef characteristics and anthropogenic variables on fish biomass and ecological functions. We performed a sensitivity analysis on all final models. For each final model, the most important seascape variable was exchanged for the same variable, but at the next most relevant buffer (i.e. in the herbivory analysis coral reef proximity at $750 \mathrm{~m}$ exchanged for coral reef proximity at $1000 \mathrm{~m})$. If the ranking of importance for variables in the model remained unchanged (i.e. in the previous examples, coral reef proximity $(1000 \mathrm{~m})$ remained the most important variable), then the results from the initial model were deemed reliable. All final models remained unchanged, providing confidence that our conclusions about the scale of influence around focal reefs are dependable. 


\section{Results}

Variability in herbivory and piscivory among reefs was strongly correlated with habitat proximity (i.e. the proximity of reefs to other coral reefs within 500 and $750 \mathrm{~m}$ ) (Table 3). These effects of habitat proximity differed, however, between the two ecological functions. Herbivory was high on reefs that were isolated from other reefs and low on reefs that were closer to other reefs, whilst piscivory was lowest on isolated reefs (Table $4 \&$ Fig. 2). By contrast, neither distance to mangroves or to seagrass were important predictors of either ecological function on coral reefs. Habitat proximity (i.e. links between focal reefs and other nearby reefs) was, therefore, a better predictor than seascape proximity (i.e. links between focal reefs and other habitats) of ecological functions on coral reefs.

Fish biomass was most strongly correlated with anthropogenic and within-reef variables. Herbivore biomass was highest on reefs close to reserves, and with low coral cover, whereas piscivore biomass peaked on reefs with high coverage of total hard substrate (Tables 3 \& 4). Herbivore assemblages were dominated by rabbitfish (Siganidae), which performed the majority (75\%) of browsing that was captured on video (Table 3). Piscivore assemblages were dominated by snappers (Lutjanidae), trevally (Carangidae) and groupers (Serranidae); and snappers were the most common predator of hardyheads (37\%) on video footage (Table 3).

Patterns in herbivory and piscivory did not correlate with the biomass of fish species that fulfil these ecological functions. Herbivory was negatively correlated with habitat proximity (i.e. highest on reefs that were isolated from other reefs), whereas the biomass of herbivorous fishes was highest on reefs near to reserves (Tables $3 \& 4$ ). Piscivory was positively correlated with habitat proximity (i.e. highest on reefs that were close to other reefs), whereas the biomass of piscivorous fishes was highest on reefs with high coverage of total hard substrate (Tables $3 \& 4$ ). 


\section{Discussion}

This study is the first to contrast the effects of habitat and seascape proximity on multiple ecological functions. Our results show that habitat proximity has opposing effects on ecological functions on inshore coral reefs, and we demonstrate that connections between coral reefs might be more important than connections between reefs and other habitats for ecosystem functioning in this system. The proximity of habitats is an important consideration in spatial conservation planning, but it is not clear how ecological functions are shaped by combined effects of multiple landscape linkages (Beger et al. 2010; Pagès et al. 2014; Olds et al. 2016). The apparent asymmetrical effects of proximity revealed here suggest that a more nuanced approach might be needed when prioritising habitat proximity in spatial conservation planning. Because habitat proximity can exert opposing effects on ecological functions, and some functions respond negatively to landscape linkages, we need explicit data on the functional effects of proximity to improve spatial conservation planning.

Contrasting responses of ecological functions to particular habitat connections have been reported elsewhere (e.g. Ferreras 2001; Bélisle 2005; Vuilleumier and Possingham 2006; Beger et al. 2010). These opposing effects of proximity on ecological functions could be rather common and might result from differences in species dispersal capabilities, or biological interactions between species from different functional groups (e.g. predators, competitors) (Lundberg and Moberg 2003; Yabsley et al. 2016). For example, herbivores might prefer to feed in safe locations where the risk of encountering their predators is low (White et al. 2003; Madin et al. 2011; Burkholder et al. 2013). Spatial separation of herbivory and predation might, therefore, be a common feature in some landscapes (Heithaus et al. 2012; Christianen et al. 2014; Madin et al. 2016). This is, however, not likely to be the reason for the opposing effects of proximity we report, because most tethered fish were consumed by predatory snappers (i.e. mesopredators), which were too small to consume the large rabbitfishes that dominated herbivory on the reefs we studied. 
In this study, both ecological functions were dominated by fish from a single family: rabbitfishes dominated herbivory (eating $75 \%$ of algae consumed), and snappers dominated piscivory (eating $37 \%$ of fish consumed). This finding suggests that coral reefs in the subtropical waters of Hervey Bay might support low functional redundancy (i.e. few species that perform similar ecological functions), with rates of herbivory and piscivory being lower than reefs in tropical waters (sensu Vergés et al. 2014). It has been suggested that low diversity and functional redundancy might be common for herbivorous fish assemblages on subtropical reefs (Yabsley et al. 2016; Gilby et al. 2017); our findings are not inconsistent with this assertion, and suggest that limited functional redundancy may also be a feature of piscivorous fish assemblages on subtropical reefs that experience high fishing pressure (Olds et al. 2012a; Martin et al. 2015).

Black rabbitfish (Siganus fuscescens) were the dominant herbivore in this study. They are browsing herbivores that consume brown and red macroalgae, and rove widely across coral reefs and migrate tidally from reefs to feed in other habitats (e.g. mangroves and seagrass) (Olds et al. 2012c; Davis et al. 2014; Yabsley et al. 2016; Gilby et al. 2017). Because black rabbitfish rove hundreds of metres between reefs and adjacent habitats (Olds et al. 2012c; Davis et al. 2014; Yabsley et al. 2016; Gilby et al. 2017), the rates at which they encountered our algae deployments might have been low. This is supported by our video data, which shows that algae assays often went undetected, but that once located they were consumed entirely. Spatial patterns of herbivory might also have been modified by the cover of natural macroalgae on reefs and the effects of nearby marine reserves, which are known to affect rates of herbivory on coral reefs elsewhere (Hoey and Bellwood 2011; Olds et al. 2012c). Isolated reefs supported a higher cover of natural macroalgae than reefs that were closer together, and were also closer to marine reserves (Appendix S1). Reefs in marine reserves in Hervey Bay support more rabbitfish than those that are open to fishing (Martin et al. 2015); our findings show that the biomass of herbivores on fished reefs also increases with proximity to marine reserves. Herbivory might, therefore, have been greater on isolated reefs 
because these areas support slightly more rabbitfish (i.e. they are closer to reserves), and more food for rabbitfish (i.e. natural macroalgae), than reefs that were closer together.

Snappers (Lutjanus carponotatus, L. fulviflamma, L. russelli) were the dominant piscivores in this study. These are mesopredators of fish and crustaceans, which migrate among coral reefs and from reefs to other habitats (e.g. mangroves and seagrass) to feed and reproduce (Grober-Dunsmore et al. 2007; Sheaves 2009). The abundance of snappers on subtropical coral reefs is often correlated with the proximity of reefs to both other reefs, and adjacent mangroves (Olds et al. 2012a; Martin et al. 2015; Engelhard et al. 2017). Higher rates of piscivory on coral reefs close to other reefs might, therefore, reflect the importance of these areas as staging points, or stepping stones, for snapper migrations, but this would need further testing in a form of a network analysis (e.g. Engelhard et al. 2017).

The presence of large numbers of herbivorous and piscivorous fishes did not necessarily always correlate with higher rates of herbivory and piscivory on coral reefs. Herbivory was negatively correlated with habitat proximity, whereas piscivory was positively correlated with proximity. By contrast, the biomass of herbivorous fishes was highest on reefs near to reserves, whereas piscivore biomass was highest on reefs with lots of hard substrate. These findings suggest that ecological functions do not always align with the diversity, abundance or perceived functional niches of particular fishes (Fox and Bellwood 2008). The discrepancies we report between ecological functions and consumer biomass might reflect diel or tidal changes in the movement biology and foraging behaviour of functionally important fishes (sensu Sheaves 2009; Nagelkerken et al. 2015; Pittman and Olds 2015). Both rabbitfishes and snappers form large schools that migrate among reefs, and between reefs and other habitats, to feed, with changes in tidal state and diel period (GroberDunsmore et al. 2007; Igulu et al. 2014; Olds et al. 2016). For example, black rabbitfish migrate from coral reefs with the rising tide to feed in adjacent mangrove forests (Olds et al. 2012a; Davis et al. 2014), whilst snappers often feed during crepuscular periods or at particular stages of the tide (Krumme 2009; Sheaves 2009; Hammerschlag et al. 2010). Our 
fish surveys might not, therefore, have always recorded fish abundance at times when functionally important species were feeding. Nevertheless, data from our video deployments confirm that rabbitfishes and tropical snappers dominated herbivory and piscivory on coral reefs in the study area.

Greater connectivity might improve conservation outcomes by enhancing the capacity of reserves to promote ecosystem functioning, but we do not know whether, and how, different ecological functions are shaped by the combined effects of multiple landscape linkages. We show that habitat proximity exerts opposing effects on two key ecological functions (i.e. herbivory and piscivory), and demonstrate that habitat linkages between reefs might be more important than the proximity of other habitats for ecosystem functions on inshore coral reefs. This finding has broad implications for conservation planning in the sea and on land. If different ecological functions have divergent responses to connectivity, prioritisation of connectivity for conservation cannot be treated as "one size fits all". Instead, conservation planners will need to tailor management solutions to prioritise the connections that most strongly influence the ecosystem functions of interest in their area. Additionally, given the paucity of information on how the spatial configuration of habitats affects ecosystem functions, we suggest that landscape and seascape conservation will benefit from developing a deeper understanding of how different spatial linkages combine to shape ecosystem functioning. 


\section{References}

Baker R, Sheaves M (2007) Shallow-water refuge paradigm: conflicting evidence from tethering experiments in a tropical estuary. Mar Ecol Prog Ser 349:13-22

Beger M, Linke S, Watts M, Game E, Treml E, Ball I, Possingham HP (2010) Incorporating asymmetric connectivity into spatial decision making for conservation. Conserv Lett 3(5):359-368

Bélisle M (2005) Measuring landscape connectivity: the challenge of behavioural landscape ecology. Ecology 86(8):1988-1995

Bennett AF (1999) Linkages in the landscape: the role of corridors and connectivity in wildlife conservation. IUCN, Norwich

Bennett S, Bellwood DR (2011) Latitudinal variation in macroalgal consumption by fishes on the Great Barrier Reef. Mar Ecol Prog Ser 426:241-U269

Berkstrom C, Gullstrom G, Lindborg R, Mwandya AW, Yahya SA, Kautsky N, Nystrom M (2012) Exploring 'knowns' and 'unknowns' in tropical seascape connectivity with insights from East African coral reefs. Estuar Coast Shelf Sci 107:1-21

Berkstrom C, Lindborg R, Thyresson M, Gullstrom M (2013) Assessing connectivity in a tropical embayment: fish migrations and seascape ecology. Biol Conserv 166:43-53

Bernhardt JR, Leslie HM (2013) Resilience to climate change in coastal marine ecosystems. Ann Rev Mar Sci 5:371-392

Bosiger YJ, McCormick MI (2014) Temporal links in daily activity patterns between coral reef predators and their prey. PLoS ONE 9(10):e111723

Bostrom C, Pittman SJ, Simenstad C, Kneib RT (2011) Seascape ecology of coastal biogenic habitats: advances, gaps, and challenges. Mar Ecol Prog Ser 427:191-217

Bregman TP, Lees AC, MacGregor HEA, Darski B, de Moura NG, Aleixo A, Barlow J, Tobias JA (2016) Using avian functional traits to assess the impact of land-cover change on ecosystem processes linked to resilience in tropical forests. Proc R Soc B Biol Sci 283(1844):10.1098/rspb.2016.1289

Brudvig LA, Damschen El, Tewksbury JJ, Haddad NM, Levey DJ (2009) Landscape connectivity promotes plant biodiversity spillover into non-target habitats. Proc Natl Acad Sci 106:9328-9332

Burkholder DA, Heithaus MR, Fourqurean JW, Wirsing A, Dill LM (2013) Patterns of topdown control in a seagrass ecosystem: could a roving apex predator induce a behaviour-mediated trophic cascade? J Anim Ecol 82(6):1192-1202

Butler IR, Sommer B, Zann M, Zhao JX, Pandolfi JM (2013) The impacts of flooding on the high-latitude, terrigenoclastic influenced coral reefs of Hervey Bay, Queensland, Australia. Coral Reefs, 32(4):1149-1163 
Christianen MJA, Herman PMJ, Bouma TJ, Lamers LPM, van Katwijk MM, van der Heide T, Mumby PJ, Silliman BR, Engelhard SL, van de Kerk M, Kiswara W, van de Koppel J (2014) Habitat collapse due to overgrazing threatens turtle conservation in marine protected areas. Proc R Soc B Biol Sci, 281(1777): 20132890

Crooks KR, Sanjayan M (2006) Connectivity conservation: maintaining connections for nature. Cambridge University Press, Cambridge

Cumming GS (2011) Spatial resilience: integrating landscape ecology, resilience, and sustainability. Landscape Ecol 26(7):899-909

Davis JP, Pitt KA, Fry B, Olds AD, Connolly R (2014) Seascape-scale trophic links for fish on inshore coral reefs. Coral Reefs 33(4):897-907

Dorenbosch M, Grol MGG, de Groene A, van der Velde G, Nagelkerken I (2009) Piscivore assemblages and predation pressure affect relative safety of some back-reef habitats for juvenile fish in a Caribbean bay. Mar Ecol Prog Ser 379:181-196

Downie RA, Babcock RC, Thomson DP, Vanderklift MA (2013) Density of herbivorous fish and intensity of herbivory are influenced by proximity to coral reefs. Mar Ecol Prog Ser 482:217-225

Dupuch A, Bertolo A, Magnan P, Dill LM (2014) Indirect effects of asymmetrical competition among top predators determine spatial patterns of predation risk for prey. Aquat Sci 76(4):543-552

Elith J, Leathwick JR, Hastie T (2008) A working guide to boosted regression trees. J Anim Ecol 77(4):802-813

Engelhard SL, Huijbers CM, Stewart-Koster B, Olds AD, Schlacher TA, Connolly RM (2017) Prioritising seascape connectivity in conservation using network analysis. J Appl Ecol, doi:10.1111/1365-2664.12824

Ferreras $P$ (2001) Landscape structure and asymmetrical inter-patch connectivity in a metapopulation of the endangered Iberian lynx. Biol Conserv 100(1):125-136

Fox RJ, Bellwood DR (2008) Remote video bioassays reveal the potential feeding impact of the rabbitfish Siganus canaliculatus (f: Siganidae) on an inner-shelf reef of the Great Barrier Reef. Coral Reefs 27(3):605-615

Froese R, Pauly D (2000) FishBase 2000: concepts, design and data sources. ICLARM, Los Baños, Laguna, Philippines, pp. 344

Gilby BL, Tibbetts IR, Stevens T (2017) Low functional redundancy and high variability in Sargassum browsing fish populations in a subtropical reef system. Mar Freshwater Res 68:331-341

Grober-Dunsmore R, Frazer TK, Lindberg WJ, Beets J (2007) Reef fish and habitat relationships in a Caribbean seascape: the importance of reef context. Coral Reefs 26(1):201-216 
Grober-Dunsmore R, Pittman SJ, Caldow C, Kendall MS, Frazer TK (2009) A landscape ecology approach for the study of ecological connectivity across tropical marine seascapes. In: Nagelkerken I (ed), Ecological connectivity among tropical coastal ecosystems. Springer, New York, pp. 493-530

Hammerschlag N, Morgan AB, Serafy JE (2010) Relative predation risk for fishes along a subtropical mangrove-seagrass ecotone. Mar Ecol Prog Ser 401:259-267

Harrison HB, Williamson DH, Evans RD, Almany GR, Thorrold SR, Russ GR, Feldheim KA, van Herwerden L, Planes S, Srinivasan M, Berumen ML, Jones GP (2012) Larval export from marine reserves and the recruitment benefit for fish and fisheries. Curr Biol 22(11):1023-1028

Heithaus MR, Wirsing AJ, Dill LM (2012) The ecological importance of intact top-predator populations: a synthesis of 15 years of research in a seagrass ecosystem. Mar Freshwat Res 63(11):1039-1050

Hoey AS, Bellwood DR (2010) Among-habitat variation in herbivory on Sargassum spp. on a mid-shelf reef in the northern Great Barrier Reef. Mar Biol 157(1):189-200

Hoey AS, Bellwood DR (2011) Suppression of herbivory by macroalgal density: a critical feedback on coral reefs? Ecol Lett 14(3):267-73

Hosmer DW, Lemeshow S (2000) Introduction to the Logistic Regression Model. Applied Logistic Regression. John Wiley \& Sons, Inc., pp. 1-30

Igulu MM, Nagelkerken I, Dorenbosch M, Grol MGG, Harborne AR, Kimirei IA, Mumby PJ, Olds AD, Mgaya YD (2014) Mangrove habitat use by juvenile reef fish: meta-analysis reveals that tidal regime matters more than biogeographic region. Plos One 9(12)

Kleyheeg E, Treep J, de Jager M, Nolet BA, Soons MB (2017) Seed dispersal distributions resulting from landscape-dependent daily movement behaviour of a key vector species, Anas platyrhynchos. J Ecol, doi:10.1111/1365-2745.12738

Kool JT, Moilanen A, Treml EA (2013) Population connectivity: recent advances and new perspectives. Landscape Ecol 28(2):165-185

Krumme U (2009) Diel and tidal movements by fish and decapods linking tropical coastal ecosystems. In: Nagelkerken I (ed), Ecological connectivity among tropical coastal ecosystems. Springer, New York, pp. 271-324

Kulbicki M, Guillemot N, Amand M (2005) A general approach to length-weight relationships for New Caledonian lagoon fishes. Cybium 29(3):235-252

Lundberg J, Andersson E, Cleary G, Elmqvist T (2008) Linkages beyond borders: targeting spatial processes in fragmented urban landscapes. Landscape Ecol 23(6):717-726

Lundberg J, Moberg F (2003) Mobile link organisms and ecosystem functioning: implications for ecosystem resilience and management. Ecosystems 6(1):0087-0098 
Madin EMP, Dill LM, Ridlon AD, Heithaus MR, Warner RR (2016) Human activities change marine ecosystems by altering predation risk. Global Change Biol 22(1):44-60

Madin EMP, Madin JS, Booth DJ (2011) Landscape of fear visible from space. Scientific Reports 1(14): 10.1038/srep00014

Magris RA, Treml EA, Pressey RL, Weeks R (2016) Integrating multiple species connectivity and habitat quality into conservation planning for coral reefs. Ecography 39(7):649-664

Mantyka CS, Bellwood DR (2007) Macroalgal grazing selectivity among herbivorous coral reef fishes. Mar Ecol Prog Ser 352:177-185

Martin TSH, Olds AD, Pitt KA, Johnston AB, Butler IR, Maxwell PS, Connolly RM (2015) Effective protection of fish on inshore coral reefs depends on the scale of mangrove-reef connectivity. Mar Ecol Prog Ser 527:157-165

Massol F, Gravel D, Mouquet N, Cadotte MW, Fukami T, Leibold MA (2011) Linking community and ecosystem dynamics through spatial ecology. Ecol Lett 14(3):313-323

Michael PJ, Hyndes GA, Vanderklift MA, Vergés A (2013) Identity and behaviour of herbivorous fish influence large-scale spatial patterns of macroalgal herbivory in a coral reef. Mar Ecol Prog Ser 482:227-240

Mueller T, Lenz J, Caprano T, Fiedler W, Böhning-Gaese K (2014) Large frugivorous birds facilitate functional connectivity of fragmented landscapes. J Appl Ecol 51(3):684-692

Nagelkerken I (2009) Evaluation of nursery function of mangroves and seagrass beds for tropical decapods and reef fishes: Patterns and underlying mechanisms. In:

Nagelkerken I (ed), Ecological connectivity among tropical coastal ecosystems.

Springer, New York, pp. 357-399

Nagelkerken I, Sheaves M, Baker R, Connolly RM (2015) The seascape nursery: a novel spatial approach to identify and manage nurseries for coastal marine fauna. Fish Fish 16(2):362-371

Nystrom M, Folke C (2001) Spatial resilience of coral reefs. Ecosystems 4(5):406-417

Olds AD, Connolly RM, Pitt KA, Maxwell PS (2012a) Habitat connectivity improves reserve performance. Conserv Lett 5(1):56-63

Olds AD, Connolly RM, Pitt KA, Maxwell PS (2012b) Primacy of seascape connectivity effects in structuring coral reef fish assemblages. Mar Ecol Prog Ser 462:191-203

Olds AD, Albert S, Maxwell PS, Pitt KA, Connolly RM (2013), Mangrove-reef connectivity promotes the effectiveness of marine reserves across the western Pacific. Glob Ecol Biogeog, 22(9):1040-1049

Olds AD, Connolly RM, Pitt KA, Pittman SJ, Maxwell PS, Huijbers CM, Moore BR, Albert S, Rissik D, Babcock RC, Schlacher TA (2016) Quantifying the conservation value of seascape connectivity: a global synthesis. Global Ecol Biogeogr 25(1):3-15 
Olds AD, Nagelkerken I, Huijbers CM, Gilby BL, Schlacher TA (2017) Connectivity in coastal seascapes. In: Pittman SJ (ed), Seascape ecology: taking landscape ecology into the sea. Wiley \& Sons, New Jersey

Olds AD, Pitt KA, Maxwell PS, Connolly RM (2012c) Synergistic effects of reserves and connectivity on ecological resilience. J Appl Ecol 49(6):1195-1203

Pagès JF, Gera A, Romero J, Alcoverro T (2014) Matrix composition and patch edges influence plant-herbivore interactions in marine landscapes. Funct Ecol 28(6):14401448

Paul V, Meyer K, Nelson S, Sanger H (1992) Deterrent effects of seaweed extracts and secondary metabolites on feeding by the rabbitfish Siganus spinus. Proc Seventh Internat Coral Reef Symp 2:867-874

Pelicice FM, Latini JD, Agostinho AA (2015) Fish fauna disassembly after the introduction of a voracious predator: main drivers and the role of the invader's demography. Hydrobiologia 746(1):271-283

Pérez-Hernández CG, Vergara PM, Saura S, Hernández J (2015) Do corridors promote connectivity for bird-dispersed trees? The case of Persea lingue in Chilean fragmented landscapes. Landscape Ecol 30(1):77-90

Peterson BJ, Valentine JF, Heck KL (2013) The snapper-grunt pump: habitat modification and facilitation of the associated benthic plant communities by reef-resident fish. J Exp Mar Biol Ecol 441:50-54

Pillans R, Franklin C, Tibbetts I (2004) Food choice in Siganus fuscescens: influence of macrophyte nutrient content and availability. J Fish Biol 64(2):297-309

Pittman SJ, Brown KA (2011) Multi-scale approach for predicting fish species distributions across coral reef seascapes. Plos One 6(5)

Pittman SJ, Olds AD (2015) Seascape ecology of fishes on coral reefs. In: Mora C. (ed), Ecology of fishes on coral reefs. Cambridge University Press, Cambridge,

Sheaves M (2009) Consequences of ecological connectivity: the coastal ecosystem mosaic. Mar Ecol Prog Ser 391:107-115

Staddon P, Lindo Z, Crittenden PD, Gilbert F, Gonzalez A (2010) Connectivity, non-random extinction and ecosystem function in experimental metacommunities. Ecol Lett 13(5):543-52

Stuart-Smith RD, Barrett NS, Crawford CM, Frusher SD, Stevenson DG, Edgar GJ (2008) Spatial patterns in impacts of fishing on temperate rocky reefs: Are fish abundance and mean size related to proximity to fisher access points? J Exp Mar Biol Ecol 365(2):116125 
Tewksbury JJ, Levey DJ, Haddad NM, Sargent S, Orrock JL, Weldon A, Danielson BJ, Brinkerhoff J, Damschen El, Townsend P (2002) Corridors affect plants, animals, and their interactions in fragmented landscapes. Proc Natl Acad Sci 99:12923-12926

Tscharntke T, Tylianakis JM, Rand TA, Didham RK, Fahrig L, Batary P, Bengtsson J, Clough Y, Crist TO, Dormann CF, Ewers RM, Frund J, Holt RD, Holzschuh A, Klein AM, Kleijn D, Kremen C, Landis DA, Laurance W, Lindenmayer D, Scherber C, Sodhi N, SteffanDewenter I, Thies C, van der Putten WH, Westphal C (2012) Landscape moderation of biodiversity patterns and processes - eight hypotheses. Biological Reviews 87(3):661685

Valentine JF, Heck KL, Jr., Blackmon D, Goecker ME, Christian J, Kroutil RM, Peterson BJ, Vanderklift MA, Kirsch KD, Beck M (2008) Exploited species impacts on trophic linkages along reef-seagrass interfaces in the Florida Keys. Ecol Appl 18(6):1501-15

Vergés A, Steinberg PD, Hay ME, Poore AGB, Campbell AH, Ballesteros E, Heck KL, Booth DJ, Coleman MA, Feary DA, Figueira W, Langlois T, Marzinelli EM, Mizerek T, Mumby PJ, Nakamura Y, Roughan M, van Sebille E, Gupta AS, Smale DA, Tomas F, Wernberg T, Wilson SK (2014) The tropicalization of temperate marine ecosystems: climatemediated changes in herbivory and community phase shifts. Proc R Soc B Biol Sci 281(1789): 20140846

Vuilleumier S, Possingham HP (2006) Does colonization asymmetry matter in metapopulations? Proc R Soc B Biol Sci 273(1594):1637-1642

White CA, Feller MC, Bayley S (2003) Predation risk and the functional response of elkaspen herbivory. For Ecol Manage 181(1-2):77-97

Yabsley NA, Olds AD, Connolly RM, Martin TSH, Gilby BL, Maxwell PS, Huijbers CM, Schoeman DS, Schlacher TA (2016) Resource type influences the effects of reserves and connectivity on ecological functions. J Anim Ecol 85(2):437-444

Zann M (2012) The use of remote sensing and field validation for mapping coral communities of Hervey Bay and the Great Sandy Strait and implications for coastal planning policy. Masters Thesis, The University of Queensland.

Zann M, Phinn S, Done T, Roelfsema C (2017) Assessing coral reef conservation values and connectivity of Hervey Bay reefs, Hervey Bay, 2006-2011. doi: 


\section{Tables:}

Table 1: List of proximity variables, within-reef characteristics and anthropogenic influences included in analyses. Proximity is the distance to nearby coral reef, mangrove and seagrass habitats within each buffer, divided by the area of that habitat enclosed by the buffer. Focal reef area is the area of the focal reef inside each buffer. Habitat richness is the number of reef, seagrass or mangrove patches inside each buffer. Habitat diversity is the number of different habitats inside each buffer.

\begin{tabular}{|c|c|c|c|}
\hline \multicolumn{2}{|l|}{ Variable type } & \multirow{2}{*}{$\begin{array}{l}\text { Variable name } \\
\text { Coral reef proximity } \\
\text { (distance/area) }\end{array}$} & \multirow{2}{*}{$\begin{array}{l}\text { Buffer scale } \\
250,500,750,1000 \mathrm{~m}\end{array}$} \\
\hline Seascape scale & Habitat proximity & & \\
\hline & $\begin{array}{l}\text { Seascape } \\
\text { proximity }\end{array}$ & $\begin{array}{l}\text { Mangrove proximity } \\
\text { (distance/area) }\end{array}$ & $250,500,750,1000 \mathrm{~m}$ \\
\hline & & $\begin{array}{l}\text { Seagrass proximity } \\
\text { (distance/area) }\end{array}$ & $250,500,750,1000 \mathrm{~m}$ \\
\hline & & Habitat richness & $250,500,750,1000 \mathrm{~m}$ \\
\hline & & Habitat diversity & $250,500,750,1000 \mathrm{~m}$ \\
\hline & & Focal reef area & $250,500,750,1000 \mathrm{~m}$ \\
\hline \multirow[t]{3}{*}{$\begin{array}{l}\text { Within-reef } \\
\text { characteristics }\end{array}$} & & Total hard substrate $^{*}$ & $\begin{array}{l}\text { Same for all scales- } \\
\text { measured at site level } \\
(\%)\end{array}$ \\
\hline & & Macroalgae cover & $\begin{array}{l}\text { Same for all scales- } \\
\text { measured at site level } \\
(\%)\end{array}$ \\
\hline & & Hard coral cover* & $\begin{array}{l}\text { Same for all scales- } \\
\text { measured at site level } \\
(\%)\end{array}$ \\
\hline \multirow[t]{2}{*}{$\begin{array}{l}\text { Anthropogenic } \\
\text { influences }\end{array}$} & & $\begin{array}{l}\text { Distance to nearest } \\
\text { boat ramp }\end{array}$ & $\begin{array}{l}\text { Same for all scales- } \\
\text { absolute distance }(\mathrm{m})\end{array}$ \\
\hline & & $\begin{array}{l}\text { Distance to nearest } \\
\text { marine reserve }\end{array}$ & $\begin{array}{l}\text { Same for all scales- } \\
\text { absolute distance }(\mathrm{m})\end{array}$ \\
\hline
\end{tabular}

* Total hard substrate encompasses the cover of solid seafloor formed by both rocks and corals, but the cover of hard corals was not correlated with the cover of total hard seafloor (Appendix S1). 
Table 2: Overview of all dependent variables measured. For lists of species categorised into browsing herbivore and piscivore groups, see Table S4 in Appendix. For binary distribution of herbivory data, see Table S5 in Appendix.

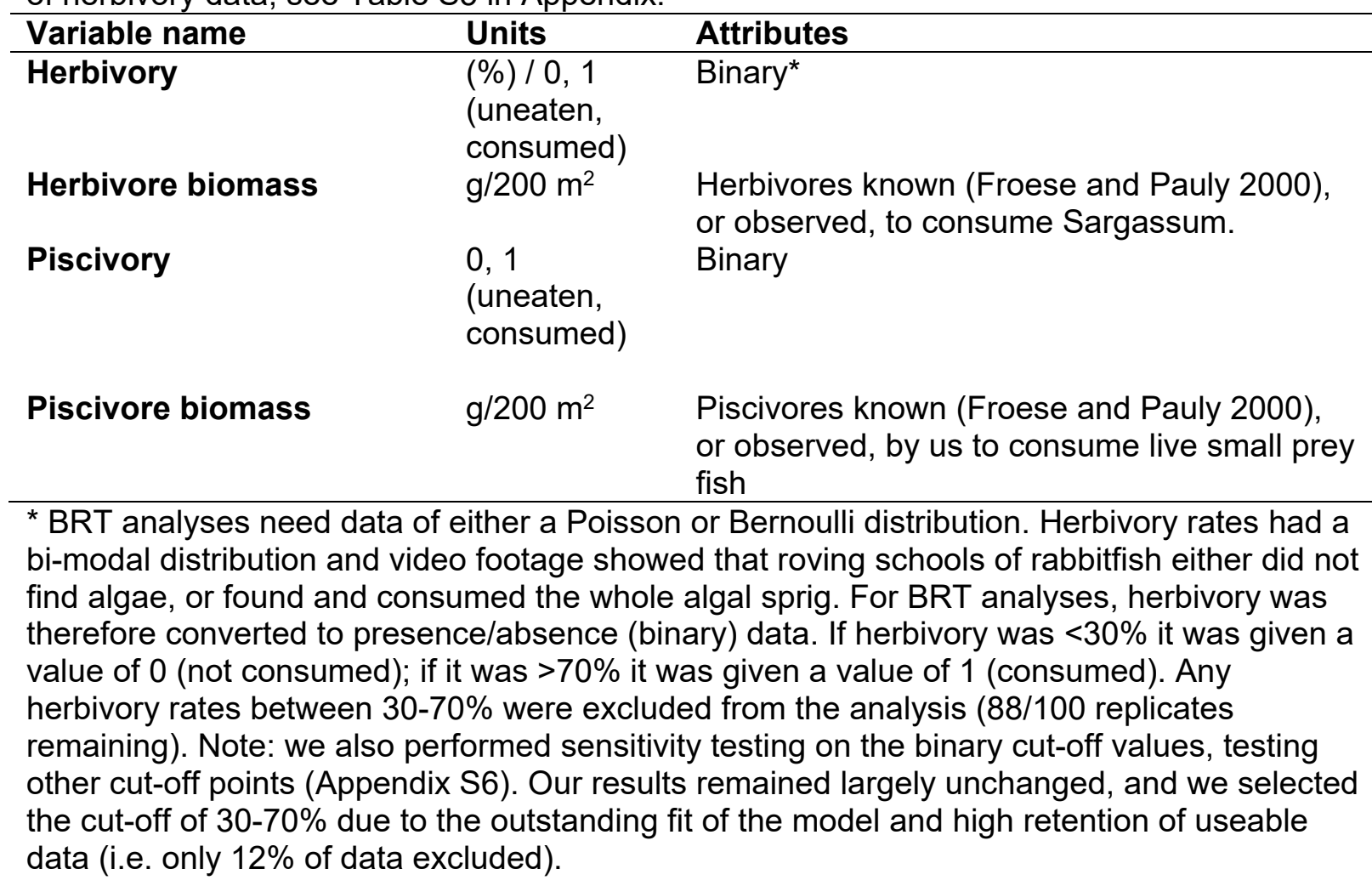


Table 3: Boosted regression tree (BRT) results for each ecological function and fish functional group. Pie charts for herbivory and piscivory represent the proportion of total herbivory and piscivory instances performed by each fish family captured on video (also includes a small number of non-fish occurrences; turtles (Cheloniidae), cephalopods, crustaceans). Pie charts for herbivore and piscivore fish biomass represent the composition of fish assemblages on each reef. Variable importance (\%) represents the percentage contribution of the variable to the final model. Variable types: habitat proximity; seascape proximity; within-reef, anthropogenic. AUC CV or Total CV measures the fit of BRT models (acceptable: >0.7; outstanding: > 0.9).

\begin{tabular}{|c|c|c|c|c|}
\hline $\begin{array}{l}\text { Function/ } \\
\text { functional } \\
\text { group }\end{array}$ & Video/assemblage data & $\begin{array}{l}\text { Variables with } \\
>10 \% \text { importance } \\
\text { to BRT }\end{array}$ & Variable type: & $\begin{array}{l}\text { AUC } \\
\text { CVI } \\
\text { Tot. CV }\end{array}$ \\
\hline
\end{tabular}

\begin{tabular}{|c|c|c|c|c|}
\hline Herbivory & $\begin{array}{l}\square \text { Cheloniidae } \\
\square \text { Monacanthidae } \\
\text { Pomacanthidae } \\
\square \text { Siganidae }\end{array}$ & $\begin{array}{l}\text { Coral reef prox } 750 \\
(68.3) \\
\text { Hard coral cover } \\
(21.7)\end{array}$ & $\begin{array}{l}\text { Habitat } \\
\text { proximity } \\
\text { Within-reef }\end{array}$ & $0.91^{\dagger}$ \\
\hline $\begin{array}{l}\text { Herbivore } \\
\text { biomass }\end{array}$ & $\begin{array}{l}\text { Kyphosidae } \\
\text { Pomacanthidae } \\
\text { Siganidae }\end{array}$ & $\begin{array}{l}\text { Distance to } \\
\text { reserve }(49.3) \\
\text { Hard coral cover } \\
(28.1) \\
\text { Hard substrate } \\
(10.3)\end{array}$ & $\begin{array}{l}\text { Anthropogenic } \\
\text { Within-reef } \\
\text { Within-reef }\end{array}$ & $0.74^{*}$ \\
\hline Piscivory & $\begin{array}{l}\text { Cephalopod } \\
\square \text { Crustacean } \\
\text { Labridae } \\
\square \text { Lutjanidae } \\
\text { Orectolobidae } \\
\text { Q Scyliorhinidae }\end{array}$ & $\begin{array}{l}\text { Coral reef prox } 500 \\
(43.1) \\
\text { Distance to ramp } \\
(37.7)\end{array}$ & $\begin{array}{l}\text { Habitat } \\
\text { proximity } \\
\text { Anthropogenic }\end{array}$ & $0.74^{\dagger}$ \\
\hline $\begin{array}{l}\text { Piscivore } \\
\text { biomass }\end{array}$ & $\begin{array}{l}\text { - Carangidae } \\
\text { - Lethrinidae } \\
\square \text { Lutjanidae } \\
\text { Serranidae } \\
\text { Sparidae } \\
\text { Q Sphyraenidae } \\
\text { Other }\end{array}$ & $\begin{array}{l}\text { Hard substrate } \\
(69) \\
\text { Habitat richness } \\
(22.2)\end{array}$ & $\begin{array}{l}\text { Within-reef } \\
\text { Seascape } \\
\text { proximity }\end{array}$ & $0.73^{*}$ \\
\hline
\end{tabular}

${ }^{\dagger}$ AUC CV used for BRT's fitted with a Bernoulli distribution (binary data: herbivory and piscivory). * Total CV used for BRT's fitted with a Poisson distribution (normally distributed biomass data). 
Table 4: Functions fitted in boosted regression tree (BRT) models relating to the distribution of herbivory, herbivore biomass, piscivory and piscivore biomass, to the most important habitat, seascape, within-reef and anthropogenic variables. The relative importance for each of the top three variables for each ecological function and fish functional group is shown in the top right corner of each plot.

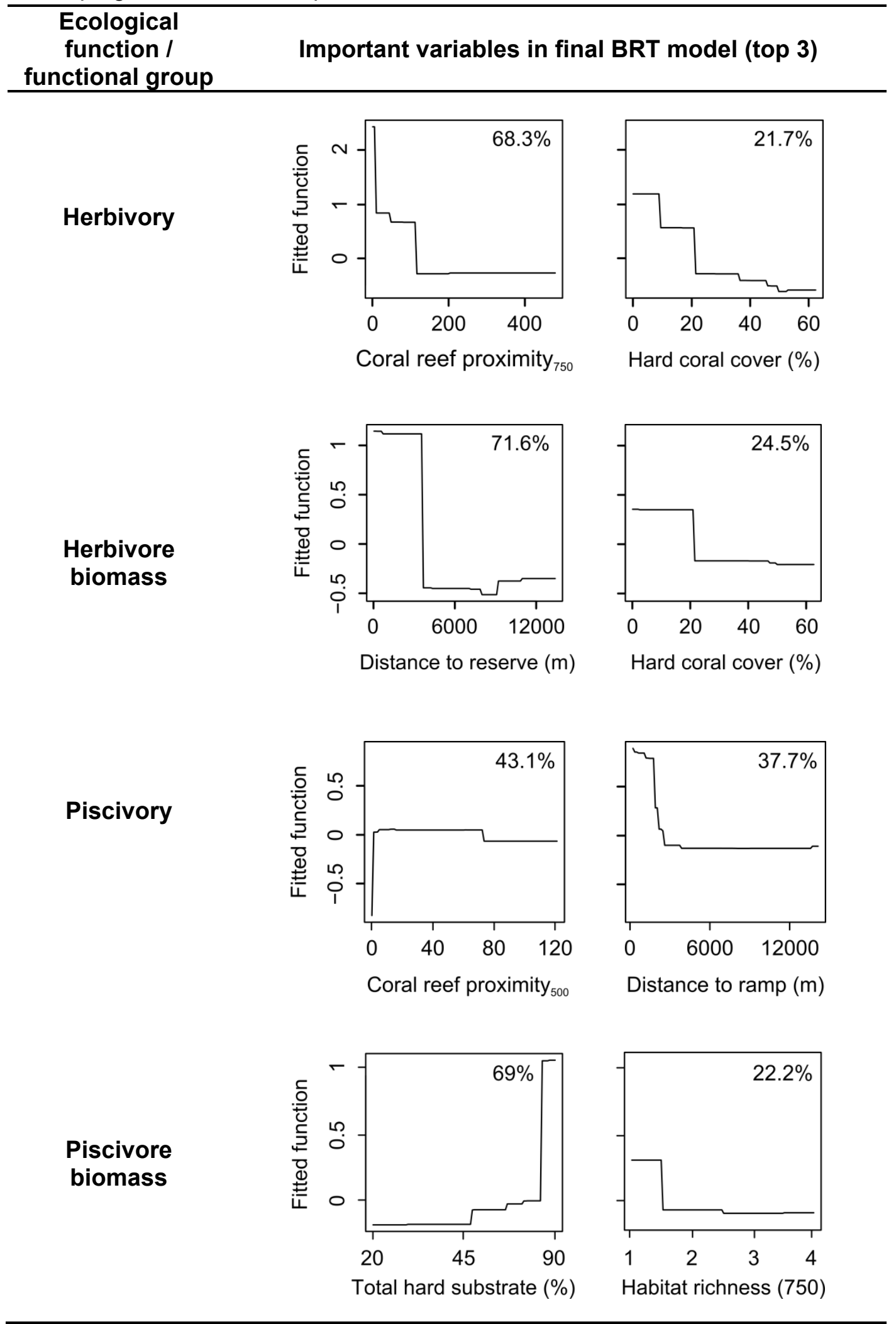


Figures:

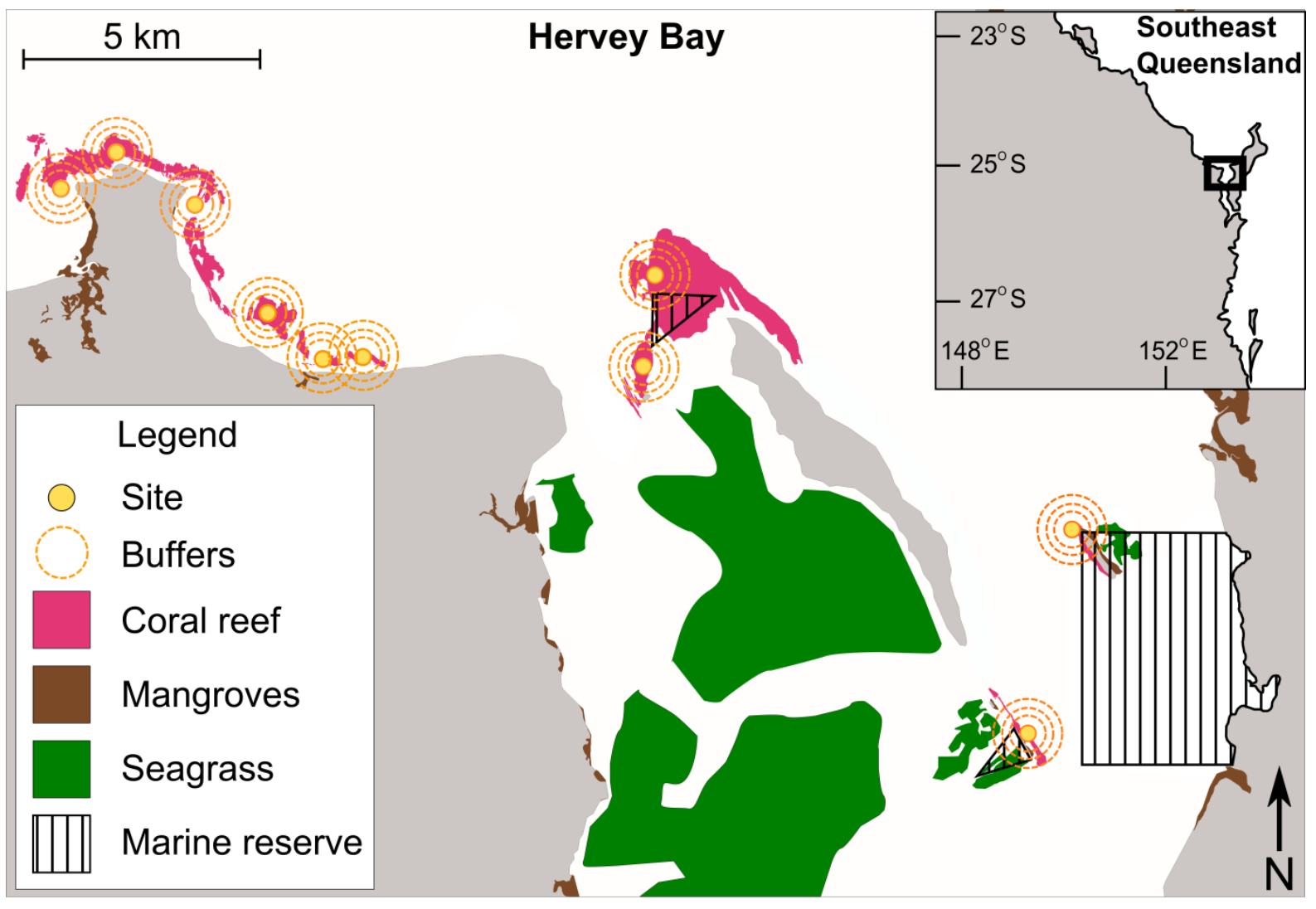

Fig. 1 Focal coral reef, mangrove and seagrass habitats of Hervey Bay, eastern Australia. Sites are shown as gold dots, with concentric buffers at radii of 250 (outline of the gold dot), 500,750 and $1000 \mathrm{~m}$ illustrating spatial scales at which seascape features were measured 


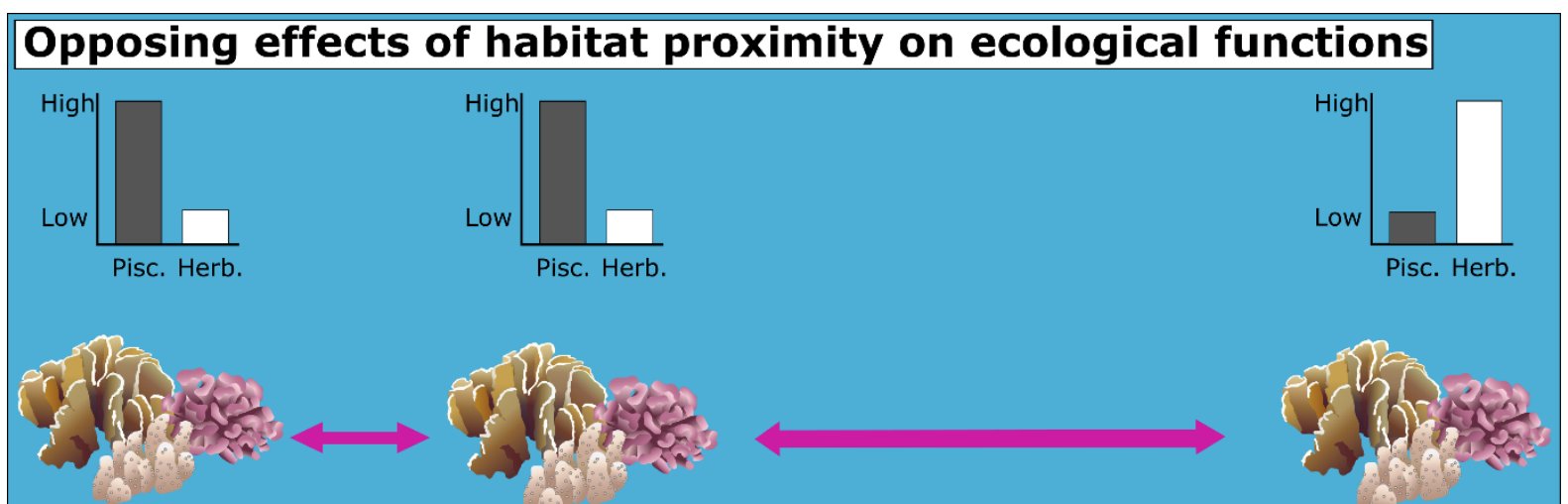

High piscivory when reefs proximal

High herbivory when reefs isolated

Fig. 2 Habitat proximity was associated with both herbivory and piscivory, but in opposing ways. Herbivory was negatively correlated with habitat proximity (i.e. highest on reefs that were isolated from other reefs), whereas piscivory was positively correlated with habitat proximity (i.e. highest on reefs that were close to other reefs) 


\section{Acknowledgements}

We thank A. Delaforce, A. Martin, K. Martin, C. Mapstone, R. Murphy and I. Pollard-Palmer for field assistance, and S. Engelhard, K. Gleeson and C. Henderson for helpful discussion of the manuscript. This study was funded by an Australian Postgraduate Award (TM). This research was carried out in accordance with Griffith University ethics guidelines under ethics approval ENV/02/16/AEC and conducted in accordance with Great Sandy Strait Marine Park research permit QS2016/GS065. 


\section{Appendix}

Table S1. Correlations between the anthropogenic and within-reef predictor variables used in the DistLM analyses.

\begin{tabular}{lcccccccc}
\hline & $\begin{array}{c}\text { Distance } \\
\text { to } \\
\text { reserve }\end{array}$ & $\begin{array}{c}\text { Distance } \\
\text { to ramp }\end{array}$ & $\begin{array}{c}\text { Hard } \\
\text { coral } \\
\text { cover }\end{array}$ & $\begin{array}{c}\text { Total } \\
\text { hard } \\
\text { substrate }\end{array}$ & $\begin{array}{c}\text { Macro } \\
\text { algae } \\
\text { cover }\end{array}$ & $\begin{array}{c}\text { Focal } \\
\text { reef } \\
\text { area } \\
\mathbf{2 5 0 )}\end{array}$ & $\begin{array}{c}\text { Focal } \\
\text { reef } \\
\text { area } \\
\mathbf{( 7 5 0 )}\end{array}$ & $\begin{array}{c}\text { Habitat } \\
\text { richness } \\
\mathbf{( 7 5 0 )}\end{array}$ \\
\hline $\begin{array}{l}\text { Distance to } \\
\text { ramp }\end{array}$ & -0.71 & & & & & & & \\
$\begin{array}{l}\text { Hard coral } \\
\text { cover }\end{array}$ & 0.41 & -0.63 & & & & & & \\
$\begin{array}{l}\text { Total hard } \\
\text { substrate }\end{array}$ & -0.07 & -0.27 & 0.63 & & & & \\
$\begin{array}{l}\text { Macroalgae } \\
\text { cover }\end{array}$ & 0.41 & -0.2 & -0.39 & -0.73 & & & \\
$\begin{array}{l}\text { Focal reef area } \\
\text { (250) }\end{array}$ & 0.21 & -0.53 & -0.04 & -0.08 & 0.28 & & \\
$\begin{array}{l}\text { Focal reef area } \\
\text { (750) }\end{array}$ & 0.14 & -0.4 & 0.07 & 0.09 & 0.31 & 0.78 & \\
$\begin{array}{l}\text { Habitat } \\
\text { richness (750) }\end{array}$ & 0.08 & 0.4 & 0.09 & 0.02 & -0.35 & -0.73 & -0.78 \\
$\begin{array}{l}\text { Coral reef } \\
\text { prox. (750) }\end{array}$ & 0.44 & -0.34 & 0.60 & 0.27 & -0.3 & -0.17 & -0.34 & \\
\hline
\end{tabular}


Table S2: Importance of each individual seascape variable across a 250, 500, 750 and $1000 \mathrm{~m}$ scales (each row represents an individual BRT). The best scale for each variable is in bold. MG, mangroves; SG, seagrass; CR, coral reef.

\begin{tabular}{|c|c|c|c|c|c|}
\hline $\begin{array}{c}\text { Ecosystem } \\
\text { process/ } \\
\text { functional group }\end{array}$ & $\begin{array}{c}\text { Seascape } \\
\text { variable }\end{array}$ & $\begin{array}{c}250 \mathrm{~m} \\
(\%)\end{array}$ & $\begin{array}{c}500 \mathrm{~m} \\
(\%)\end{array}$ & $\begin{array}{c}750 \mathrm{~m} \\
(\%)\end{array}$ & $\begin{array}{c}1000 \mathrm{~m} \\
(\%)\end{array}$ \\
\hline \multirow{6}{*}{ Herbivory } & MG & 1 & 39 & 23 & 37 \\
\hline & SG & 100 & 0 & 0 & 0 \\
\hline & $\mathrm{CR}$ & 0 & 8 & 61 & 31 \\
\hline & Focal reef area & 60 & 19 & 21 & 0 \\
\hline & Habitat richness & 41 & 14 & 40 & 4 \\
\hline & Habitat diversity & 55 & 5 & 11 & 28 \\
\hline \multirow{6}{*}{$\begin{array}{l}\text { Herbivore } \\
\text { biomass }\end{array}$} & MG & 0 & 15 & 15 & 70 \\
\hline & SG & na & na & na & na \\
\hline & $\mathrm{CR}$ & 0 & 7 & 51 & 42 \\
\hline & Focal reef area & 42 & 25 & 33 & 0 \\
\hline & Habitat richness & 8 & 6 & 62 & 24 \\
\hline & Habitat diversity & na & na & na & na \\
\hline \multirow{5}{*}{ Piscivory } & MG & 18 & 56 & 15 & 11 \\
\hline & SG & 100 & 0 & 0 & 0 \\
\hline & CR & 0 & 52 & 35 & 13 \\
\hline & Focal reef area & 42 & 5 & 8 & 0 \\
\hline & Habitat richness & 45 & 37 & 6 & 3 \\
\hline \multirow{7}{*}{$\begin{array}{c}\text { Piscivore } \\
\text { biomass }\end{array}$} & Habitat diversity & 45 & 40 & 10 & 6.2 \\
\hline & MG & 0 & 2 & 3 & 95 \\
\hline & SG & na & na & na & na \\
\hline & CR & 0 & 3 & 55 & 42 \\
\hline & Focal reef area & 43 & 10 & 47 & 0 \\
\hline & Habitat richness & 0 & 3 & 95 & 3 \\
\hline & Habitat diversity & 0 & 1 & 1 & 98 \\
\hline
\end{tabular}


Table S3: Results from BRT's run on each functional group containing only seascape variables.

\begin{tabular}{llll}
\hline $\begin{array}{l}\text { Ecosystem } \\
\text { process/ } \\
\text { functional group }\end{array}$ & $\begin{array}{l}\text { Seacape-scale/ within-reef variables with } \\
\mathbf{1 0 \%} \text { importance to BRT (\% importance) }\end{array}$ & $\begin{array}{l}\text { AUC } \\
\mathbf{C V}^{\dagger} / \\
\text { Total }_{\mathbf{C V}^{*}}\end{array}$ & $\begin{array}{l}\text { No. of } \\
\text { trees }\end{array}$ \\
\hline $\begin{array}{l}\text { Herbivory } \\
\begin{array}{l}\text { Herbivore } \\
\text { biomass }\end{array}\end{array}$ & $\begin{array}{l}\text { Coral reef prox } \\
500\end{array}$ & $0.94^{\dagger}$ & 3450 \\
$\begin{array}{l}\text { Piscivory } \\
\begin{array}{l}\text { Piscivore } \\
\text { biomass }\end{array}\end{array}$ & Coral reef prox & $0.72^{*}$ & 900 \\
\hline
\end{tabular}

${ }^{\dagger}$ AUC CV used for BRT's fitted with a Bernoulli distribution (binary data). ${ }^{*}$ Total CV used for BRT's fitted with a Poisson distribution (normal data). 
Table S4: Species included in piscivore and browsing herbivore groups. Note: these species are either known piscivores and browsers (Froese \& Pauly 2000) or were seen to be consuming live hardyheads or sargassum on our video footage.

\begin{tabular}{|c|c|}
\hline $\begin{array}{c}\text { Functional } \\
\text { group }\end{array}$ & Species included \\
\hline Piscivores & $\begin{array}{l}\text { Acanthopagrus australis, Cephalopholis argus, Dasyatidae spp, } \\
\text { Epinephelus coioides, Epinephelus merra, Epinephelus quoyanus, } \\
\text { Gnathanodon speciosus, Gymnothorax favagineus, Lethrinus laticaudis, } \\
\text { Lutjanus carponotatus, Lutjanus fulviflamma, Lutjanus russelli, } \\
\text { Platycephalus fuscus, Plectropomus maculatus, Psammoperca } \\
\text { waigiensis, Pseudolabrus guentheri, Sargocentron rubrum, Sphyraena } \\
\text { obtusa }\end{array}$ \\
\hline $\begin{array}{l}\text { Browsing } \\
\text { herbivores }\end{array}$ & $\begin{array}{l}\text { Siganus fuscescens, Chaetodontoplus duboulayi, Kyphosus } \\
\text { sydneyanus, Monacanthus chinensis }\end{array}$ \\
\hline
\end{tabular}




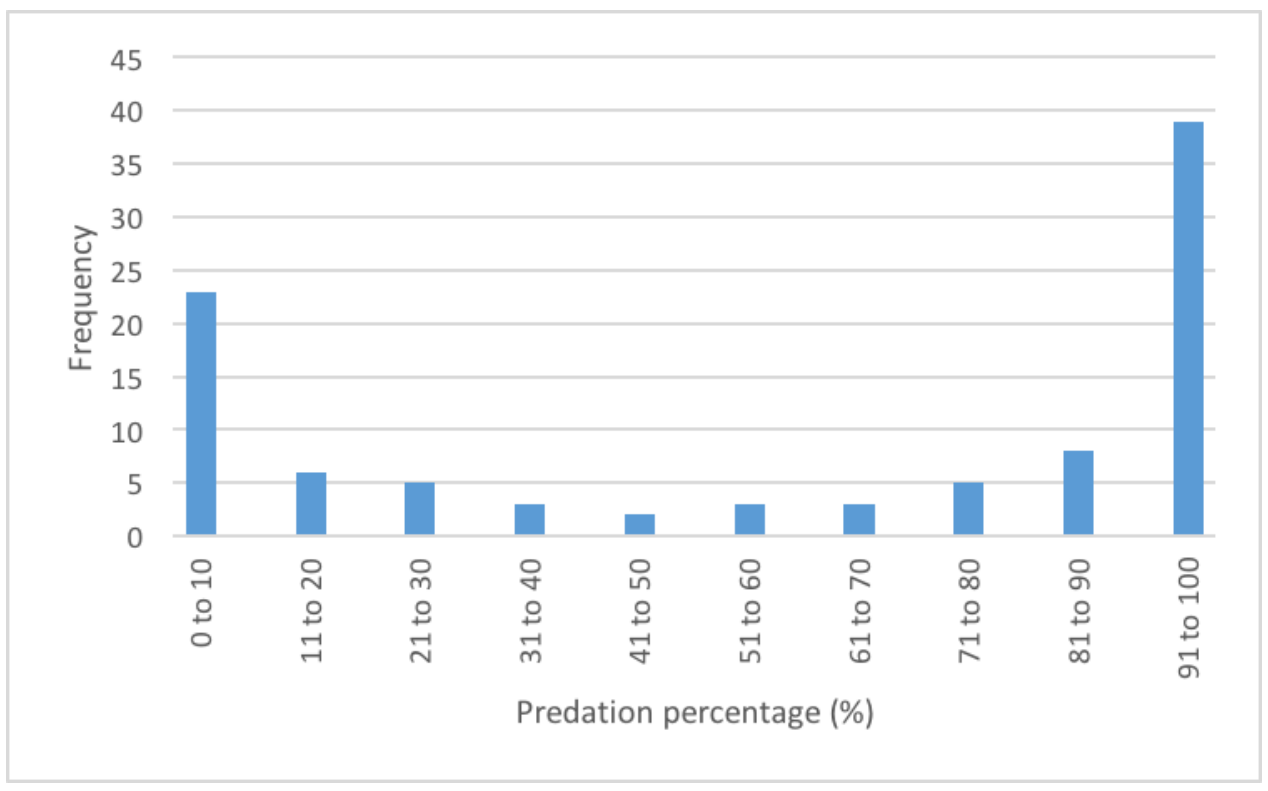

Figure S5: Binary distribution of herbivory data. Most assays were either wholly consumed, or untouched. Due to this bi-modal distribution herbivory data was therefore converted to presence/absence (binary) data. If herbivory was $\leq 30 \%$ it was given a value of 0 (not consumed); if it was $\geq 70 \%$ it was given a value of 1 (consumed). Any herbivory rates between $30-70 \%$ were excluded from the analysis (88/100 replicates remaining).

Table S6: Results from sensitivity testing on binary cut-off for herbivory data.

\begin{tabular}{lllll}
\hline $\begin{array}{l}\text { Ecosystem } \\
\text { process }\end{array}$ & Cut off & $\begin{array}{l}\text { Seascape-scale/ within- } \\
\text { reef variables with }>10 \% \\
\text { importance to BRT }(\% \\
\text { importance) }\end{array}$ & $\begin{array}{l}\text { AUC } \\
\text { CV }\end{array}$ & $\begin{array}{l}\text { No. of } \\
\text { trees }\end{array}$ \\
\hline Herbivory & $\begin{array}{l}\text { If } x \leq 30,0 ; \\
\text { If } x \geq 70,1\end{array}$ & Coral reef prox $750(86)$ & 0.91 & 4350 \\
Herbivory & If $x \leq 20,0 ;$ & Coral reef prox $750(90)$ & 0.95 & 2800 \\
If $x \geq 80,1$ & Coral reef prox $750(81)$ & 0.96 & 2800 \\
Herbivory & If $x \leq 10,0 ;$ & & & \\
Herbivory & If $x \geq 90,1$ & Coral reef prox $750(90)$ & 0.91 & 3250 \\
\hline
\end{tabular}

